\title{
TANGGUNG JAWAB PEMEGANG SAHAM PERSEROAN TERBATAS MENURUT HUKUM POSITIF
}

\author{
Kurniawan* \\ Bagian Hukum Bisnis, Fakultas Hukum Universitas Mataram, Mataram \\ Jalan Majapahit Nomor 62 Mataram, Lombok, Nusa Tenggara Barat 83125
}

\begin{abstract}
Limited Liability Companies have completeness instrument called organ corporation which consists of General Meeting of Shareholders (GMS), the board of directors, and the board of commissioners. According to Commercial Law (KUHD), Act No. 1 of 1995 jo. Act No. 40 of 2007 on Limited Liability Companies, the principle liability of General Meeting of Shareholders (GMS) is limited on their share. But, if it is proven that, among others, there has been a mixing of the shareholder's personal assets and the Company's assets, so the limited liability turns into unlimited liability or personal liability.
\end{abstract}

Keywords: GMS, limited liability companies, limited liability.

\section{Intisari}

Perseroan Terbatas (PT) memiliki alat kelengkapan yang disebut organ perseroan terdiri dari Rapat Umum Pemegang Saham (RUPS), Direksi dan Dewan Komisaris. Menurut Kitab Undang-Undang Hukum Dagang (KUHD), UU PT No. 1 Tahun 1995 jo. UU PT No. 40 Tahun 2007, tanggung jawab Pemegang Saham (RUPS) pada prinsipnya adalah bersifat terbatas pada saham yang dimiliki. Akan tetapi, apabila dapat dibuktikan bahwa telah terjadi pembauran harta kekayaan pribadi Pemegang Saham dengan harta kekayaan perseroan, maka tanggung jawab terbatas tersebut akan berubah menjadi tanggung jawab tidak terbatas atau tanggung jawab pribadi.

Kata Kunci: RUPS, perseroan terbatas, tanggung jawab terbatas.

\section{Pokok Muatan}

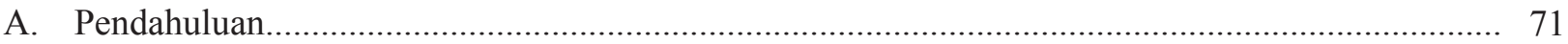

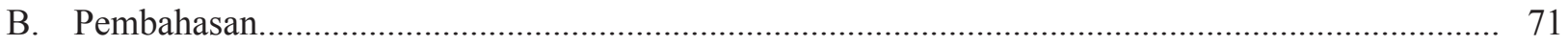

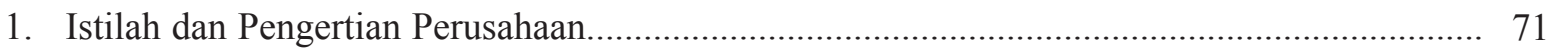

2. Pengertian, Anggaran Dasar, dan Status Badan Hukum PT.................................................... 72

3. Pengertian, Kedudukan dan Kewenangan Pemegang Saham................................................. 73

4. Tanggung Jawab Pemegang Saham PT menurut Hukum Positif.............................................. 75

5. Beralihnya Tanggung Jawab Terbatas Menjadi Tanggung Jawab Tak Terbatas Pemegang

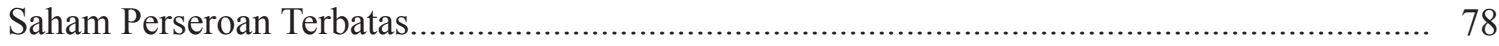

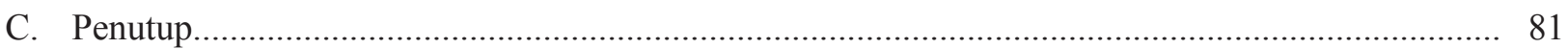

Alamat korespondensi: kurniawan3377@yahoo.co.id 


\section{A. Pendahuluan}

Perusahaan merupakan salah satu sendi utama dalam kehidupan masyarakat modern, karena merupakan salah satu pusat kegiatan manusia untuk memenuhi kehidupan kesehariannya. Kegiatan perusahaan merupakan bagian dari kegiatan ekonomis yang dilakukan oleh suatu organisasi, secara terbuka dan berkesinambungan, mengenai suatu barang baik yang bergerak dan tidak bergerak maupun bidang jasa, bersaing mutu atau kualitas dengan tujuan untuk memperoleh laba atau keuntungan.

Usaha perusahaan atau yang menjalankan perusahaan, sesungguhnya merupakan padanan kata dari pedagang atau kegiatan perdagangan, yang maknanya melakukan kegiatan terus-menerus, secara terang-terangan dalam rangka mencari keuntungan. ${ }^{1}$ Membicarakan tentang perusahaan, tidak akan terlepas dari bahasan tentang bentuk-bentuk badan usaha tersebut. Pada Hukum Dagang Indonesia dikenal bentuk-bentuk badan usaha seperti Perseroan Firma (Fa), Perseroan Komanditer (CV/ Commanditaire Vennootschap), dan Perseroan Terbatas (PT).

Perseroan Terbatas sebagai perusahaan bisnis sedikitnya memiliki lima karakteristik struktural yaitu: (1) legal personality (badan hukum); (2) limited liability (tanggung jawab terbatas); (3) transferable shares (saham dapat dialihkan); (4) centralized management (manajemen terpusat); dan (5) shared ownership (pemilikan saham oleh pemasuk modal). ${ }^{2}$ Perseroan Terbatas mempunyai alat yang disebut organ perseroan, yang bermanfaat untuk menggerakkan perseroan agar badan hukum dapat berjalan sesuai dengan tujuannya. Organ perseroan terbatas terdiri dari Rapat Umum Pemegang Saham (RUPS), Direksi, dan Dewan Komisaris.

Perseroan sebagai badan hukum berarti perseroan merupakan subyek hukum, sehingga perseroan tersebut dapat dibebani hak dan kewajiban seperti halnya manusia pada umumnya. Sebagai badan hukum, perseroan mempunyai kekayaan sendiri yang terpisah dengan kekayaan pengurusnya. Tanggung jawab pemegang saham terbatas pada saham yang dimilikinya, akan tetapi jika dapat dibuktikan bahwa telah terjadi pembauran harta kekayaan pribadi pemegang saham dengan harta kekayaan perseroan, maka tanggung jawab terbatas akan berubah menjadi tanggung jawab tidak terbatas, artinya pemegang saham ikut bertanggung jawab secara pribadi terhadap kerugian perseroan, tidak lagi sebatas saham yang dimilikinya dalam perseroan saja sebagaimana prinsip pertanggungjawaban yang dianut sebuah badan hukum. Permasalahan yang diangkat dalam penelitian ini adalah bagaimana tanggung jawab pemegang saham dalam perseroan terbatas menurut hukum positif dan bilamana terjadi peralihan tanggung jawab pemegang saham secara terbatas menjadi tak terbatas?

\section{B. Pembahasan \\ 1. Istilah dan Pengertian Perusahaan}

Istilah perusahaan (bedrijf atau ondernering) merupakan suatu pengertian ekonomi yang termuat dalam Pasal 6 KUHD, namun demikian apabila ditelusuri dalam KUHD yang demikian luasnya tidak membuat rumusan atau penafsiran otentik atau penjelasan resmi secara yuridis mengenai arti dari perusahaan. H.M.N. Purwosutjipto, mengemukakan bahwa istilah perusahaan lahir sebagai wujud perkembangan yang terjadi dalam dunia usaha yang kemudian diakomodir dalam KUHD. Masuknya, istilah Perusahaan dalam KUHD diawali dengan ditemukannya beberapa kekurangan atau kelemahan dalam KUHD. Namun, istilah Perusahaan ini tidak dirumuskan secara eksplisit seperti apa yang terjadi dalam istilah Pedagang dan Pebuatan Perdagangan. ${ }^{3}$ Sebagai wujud keberadaan dan penerimaan istilah Perusahaan dalam KUHD, bisa diperhatikan rumusan pasal-pasal antara lain sebagai berikut:

a. $\quad$ Pasal 6 ayat (1) KUHD: "Setiap orang yang menyelenggarakan perusahaan diwajibkan

Sri Redjeki Hartono, 2000, Kapita Selekta Hukum Perusahaan, Mandar Maju, Bandung, hlm. v.

Henry Hansmann, et al., "What is: Corporate Law?", dalam Reiner Kraakman, et al., 2004, The Anatomy of Corporate Law A Comparative and Functional Approach, Oxford University Press, New York, hlm. 1.

H.M.N. Purwosutjipto, 1995, Pengertian Pokok Hukum Dagang Indonesia 1: Pengetahuan Dasar Hukum Dagang, Djambatan, Jakarta, hlm. 5 . 
untuk membuat catatan-catatan menurut syarat-syarat perusahaannya tentang keadaan hartanya dan tentang apa saja yang berhubungan dengan perusahaannya, dengan cara yang demikian sehingga dari catatan-catatan yang diselenggarakan itu sewaktu-waktu dapat diketahui segala hak dan kewajibannya".

b. Pasal 16 KUHD: "Firma adalah suatu perusahaan yang didirikan untuk menjalankan suatu usaha dengan nama bersama".

c. Pasal 36 ayat (1) KUHD: "Perseroan Terbatas tidaak mempunyai Firma, dan tidak memakai nama salah seorang atau lebih dari para persero, melainkan mendapat namanya hanya dari tujuan perusahaan saja".

Istilah "Perusahaan" adalah istilah yang lahir sebagai akibat adanya pembaharuan dalam Hukum Dagang. Oleh karena itulah, sejak beberapa pasal dalam Buku I KUHD dicabut, maka sejak saat itu pula istilah dan pengertian pedagang dan perbuatan perdagangan (perniagaan) tidak layak lagi mewakili kepentingan kaum pedagang khususnya dan masyarakat pada umumnya yang kemungkinan memiliki hubungan, kepentingan dan atau ikut ambil bagian dalam aktivitas perusahaan. Berikut ini dikemukakan beberapa pengertian perusahaan baik menurut ahli maupun menurut perundang-undangan, yaitu:

a. Mahkamah Agung Belanda (Hoge Raad) telah memberi definisi dalam arrest 25 November 1925, bahwasanya "dianggap ada suatu perusahaan kalau seseorang menyelenggarakan sesuatu secara teratur (sifatnya terus-menerus; ada pembukuan, penulis), yang ada hubungannya dengan menjalankan perdagangan untuk mendapatkan keuntungan berupa uang". ${ }^{4}$

b. Rachmadi Usman, mengemukakan perusahaan adalah badan usaha yang menjalankan kegiatan di bidang perekonomian (keuangan, industri, dan perdagangan), yang dilakukan secara terus-menerus atau teratur (regelmatig), terang-terangan (openlijk), dan dengan tujuan memperoleh keuntungan dan atau laba (wints oogmerk). ${ }^{5}$

c. Pasal 1 huruf b UU No. 3 Tahun 1982 tentang Wajib Daftar Perusahaan, pengertian perusa- haan adalah setiap bentuk usaha yang menjalankan usaha yang bersifat tetap, terus menerus dan berkedudukan di wilayah RI untuk memperoleh keuntungan dan atau laba.

d. Pasal 1 butir 2 UU No. 8 Tahun 1997 tentang Dokumen Perusahaan, pengertian perusahaan adalah setiap bentuk usaha yang melakukan kegiatan secara tetap dan terusmenerus dengan tujuan memperoleh keuntungan atau laba, baik yang diselenggarakan oleh orang perorangan maupun badan usaha yang berbentuk badan hukum ataubukan badan hukum, yang didirikan dan berkedudukan dalam wilayah Negara Kesatuan Republik Indonesia.

\section{Pengertian, Anggaran Dasar, dan Status Badan Hukum PT}

Perseroan Terbatas (selanjutnya disingkat PT) berasal dari istilah hukum Dagang Belanda Wetboek van Koophandel (WvK) yaitu Naamloze Vennootschap dengan singkatan NV. Istilah perseroan terbatas terdiri dari dua kata, yaitu perseroan dan terbatas. Perseroan merujuk pada modal PT yang terdiri atas sero-sero atau saham-saham. Adapun kata terbatas merujuk pada tanggung jawab peme-gang saham yang luasnya hanya terbatas pada nilai nominal semua saham yang dimilikinya. ${ }^{6}$ Perseroan Terbatas pertama kali diatur di Indonesia melalui Pasal 36 sampai dengan Pasal 56 KUHD.

Menurut Sri Redjeki Hartono, perseroan terbatas adalah sebuah persekutuan untuk menjalankan perusahaan tertentu dengan menggunakan suatu modal dasar yang dibagi dalam sejumlah saham atau sero tertentu, masing-masing berisikan jumlah uang tertentu pula ialah jumlah nominal, sebagai ditetapkan dalam akta notaris pendirian perseroan terbatas, akta mana wajib dimintakan pengesahannya oleh Menteri Kehakiman, sedangkan untuk jadi sekutu diwajibkan menempatkan penuh dan menyetor jumlah nominal dari sehelai saham atau lebih. $^{7}$

Pasal 1 butir 1 Undang-Undang No. 1 Tahun 1995 tentang Perseroan Terbatas (selanjutnya

\footnotetext{
R. Suryatin, 1982, Hukum Dagang, Pradnya Paramita, Jakarta, hlm. 12.

Rachmadi Usman dalam Abdul R Saliman, et al., 2004, Esensi Hukum Bisnis Indonesia, Kencana, Jakarta. hlm. 54

Ridwan Khairandy, "Perseroan Terbatas Sebagai Badan Hukum”, Jurnal Hukum Bisnis, Vol. 26, No. 3, 2007, hlm. 5.

Sri Redjeki Hartono, 1985, Bentuk Bentuk Kerjasama dalam Dunia Niaga, Fakultas Hukum Universitas 17 Agustus 1945, Semarang, hlm.47.
} 
disingkat UU PT No. 1 Tahun 1995), memberikan definisi Perseroan Terbatas adalah badan hukum yang didirikan berdasarkan perjanjian, melakukan kegiatan usaha dengan modal dasar yang seluruhnya terbagi dalam saham, dan memenuhi persyaratan yang ditetapkan dalam UU ini. ${ }^{8}$ Pengertian ini kemudian disempurnakan dalam Pasal 1 UndangUndang No. 40 Tahun 2007 tentang Perseroan Terbatas (selanjutnya akan disingkat UU PT No. 40 Tahun 2007), dimana definisi Perseroan Terbatas yang selanjutnya disebut perseroan adalah badan hukum yang merupakan persekutuan modal, didirikan berdasarkan perjanjian, melakukan kegiatan dengan modal dasar yang seluruhnya terbagi dalam saham dan memenuhi persyaratan yang ditetapkan dalam undang-undang ini serta peraturan pelaksanaannya.

Anggaran Dasar (selanjutnya disingkat AD) merupakan bagian dari akta pendirian PT. Sebagai bagian dari akta pendirian, AD memuat aturan main dalam perseroan, yang menentukan setiap hak dan kewajiban dari pihak-pihak dalam AD, baik perseroan itu sendiri, Pemegang Saham, Dewan Komisaris maupun pengurus (Direksi) PT tersebut. Hal ini diperkuat dengan adanya ketentuan Pasal 18 UU PT No. 40 Tahun 2007, yang menyatakan bahwa "Perseroan harus mempunyai maksud dan tujuan serta kegiatan usaha yang dicantumkan dalam AD perseroan sesuai dengan ketentuan perundang-undangan". 9 AD merupakan aturan main perseroan, yang tidak hanya mengikat para pihak yang mengadakannya, tetapi juga pihak ketiga lainnya yang berhubungan hukum dengan perseroan, termasuk di dalamnya para pemegang saham, pengurus (Direksi) dan Dewan Komisaris perseroan. ${ }^{10}$ Pasal 15 ayat (1) UU PT No. 40 Tahun 2007, menjelasakan bahwa AD suatu PT harus memuat halhal sebagai berikut: ${ }^{11}$

a. Nama dan tempat kedudukan PT;

b. Maksud dan tujuan serta kegiatan usa-

ha perseroan;

c. Jangka waktu berdirinya perseroan;

d. Besarnya jumlah modal dasar, modal ditempat dan modal disetor;

e. Jumlah saham, klasifikasi saham apabila ada berikut jumlah saham untuk tiap klasifikasi, hak-hak yang melekat pada setiap saham, dan nilai nominal setiap saham;

f. Nama dan jumlah anggota Direksi, dan Dewan Komisaris;

g. Penetapan tempat dan tata cara penyelenggaraan RUPS;

h. Tata cara pengangkatan, penggantian, pemberhentian anggota Direksi dan Dewan Komisaris;

i. Tata cara penggunaan laba dan pembagian deviden.

Selain ketentuan hal-hal yang harus dimuat sebagaimana Pasal 15 ayat (1) di atas, ayat (2) dan (3) juga menyatakan bahwa AD PT juga dapat memuat ketentuan lain yang tidak bertentangan dengan UU PT. Selain itu, AD PT tidak boleh memuat ketentuan tentang penerimaan bunga tetap atas sama, dan ketentuan tentang pemberian manfaat pribadi kepada pendiri atau pihak lain.

Setelah mendapatkan pengesahan dari Menteri Hukum dan Hak Asasi Manusia (HAM), maka PT telah sah sebagai badan hukum dan menjadi dirinya sendiri serta dapat melakukan perjanjianperjanjian dan kekayaan perseroan terpisah dari kekayaan pemiliknya. Sejak sebuah PT berstatus sebagai badan hukum, maka sejak saat itu hukum memperlakukan Pemegang Saham dan pengurus (Direksi) terpisah dari PT itu sendiri yang dikenal dengan istilah: "separate legal personality" yaitu sebagai individu yang berdiri sendiri. Dengan demikian pemegang saham yang tidak mempunyai kepentingan dalam kekayaan PT, juga tidak bertanggung jawab atas utang-utang perusahaan atau PT. ${ }^{12}$

\section{Pengertian, Kedudukan dan Kewenangan}

\footnotetext{
Pasal 1 angka 1 Undang-Undang Nomor 1 Tahun 1995 tentang Perseroan Terbatas (Lembaran Negara Republik Indonesia Nomor 13 Tahun 1995, Tambahan Lembaran Negara Republik Indonesia Nomor 3587).

9 Pasal 18 Undang-Undang Nomor 40 Tahun 207 tentang Perseroan Terbatas (Lembaran Negara Nomor 106 Tahun 2007, Tambahan Lembaran Negara Republik Indonesia Nomor 4756).

10 Ahmad Yani, et al., 1999, Seri Hukum Bisnis Perseroan Terbatas, RajaGrafindo, Jakarta, hlm. 30.

11 Pasal 15 ayat (1) Undang-Undang Nomor 40 Tahun 2007 tentang Perseroan Terbatas (Lembaran Negara Nomor 106 Tahun 2007, Tambahan Lembaran Negara Republik Indonesia Nomor 4756).

12 I.G. Widjaja, 2003, Hukum Perusahaan, Mega Poin, Blanc, Jakarta, hlm. 6.
} 


\section{Pemegang Saham}

Pemegang Saham melalui Rapat Umum Pemegang Saham (selanjutnya disingkat RUPS) adalah alat perlengkapan perseroan, yang merupakan kekuasaan yang tertinggi ${ }^{13}$ dalam perseroan, yang melaksanakan pimpinan tertinggi atas perusahaan. ${ }^{14}$ Pasal 1 butir 4 UU PT No.40 Tahun 2007 menjelaskan bahwa "Rapat Umum Pemegang Saham (selanjutnya disebut RUPS) adalah organ perseroan yang mempunyai wewenang yang tidak diberikan kepada Direksi atau Dewan Komisaris dalam batas yang ditentukan dalam Undang-Undang ini dan/ atau Anggaran Dasar". ${ }^{15}$ Namun wewenang yang diberikan Undang-Undang kepada RUPS tidak berarti RUPS dapat melakukan tugas dan wewenang yang diberikan Undang-Undang kepada Direksi dan Komisaris. Dari pengertian Pasal 1 butir 4 UU PT No. 40 Tahun 2007, dapat disimpulkan beberapa hal, yaitu sebagai berikut: ${ }^{16}$

a. Organ ini berupa rapat. hal yang harus dicermati adalah forum rapat berbeda dengan individu pemegang saham. Jadi, sekalipun seseorang misalnya menjadi pemegang saham mayoritas, secara individu tidak memegang kekuasaan (tertinggi) dalam perseroan. Kekuasaan tertinggi baru muncul apabila diselenggarakan rapat dan rapat tersebut harus memenuhi persyaratan formalitas tertentu yang telah diatur dalam UU PT.

b. Kewenangan atau otoritas yang dimiliki oleh forum rapat ini adalah kewenangan yang tersisa berdasarkan teori residual. kewenangan ini pada dasarnya lahir dari status kepemilikan perseroan yang ada di tangan pemegang saham. pemegang saham adalah (bagian) pemilik perseroan. Secara teoritis, sebagai pemilik ia memegang hak untuk melakukan tindakan apa saja terhadap benda yang dimilikinya. c. Kewenangan yang ada pada forum rapat ini (sebagaian) dapat didelegasikan kepada organ yang lain, yaitu Direksi dan Dewan Komisaris. Keleluasaan kewenangan yang didelegasikan dapat diatur dalam UU PT dan/atau Anggaran Dasar PT atau melalui keputusan RUPS. Kewenangan yang didelegasikan sejatinya apa yang bersifat sementara dan ada yang bersifat tetap. Kewenangan pendelegasian yang bersifat tetap misalnya kepengurusan perusahaan (secara umum) dan fungsi refresentasi (mewakili perusahaan di dalam maupun di luar pengadilan). Sedangkan pendelegasian yang bersifat sementara sewaktu-waktu dapat dicabut.

Hal ini senada dengan pendapat Munir Fuady, bahwa secara prinsip yang merupakan organ perusahaan bukan pemegang sahamnya, tetapi Rapat Umum Pemegang Saham tersebut. ${ }^{17}$ Sebab dalam banyak hal (walaupun tidak selamanya), pemegang saham hanya dapat bertindak lewat mekanisme RUPS, hanya dalam beberapa hal saja pemegang saham dapat bertindak lewat mekanisme RUPS, sehingga dalam hal ini, pihak pemegang saham (bukan Rapat Umum Pemegang Saham) juga telah cenderung menjadi organ perusahaan yang keempat di samping Direktur, Dewan Komisaris, dan Rapat Umum Pemegang Saham. Sebagai organ perseroan yang paling tinggi dan berkuasa untuk menentukan arah dan tujuan perseroan, RUPS memiliki segala wewenang yang tidak diberikan kepada Direksi dan Dewan Komisaris PT. RUPS mempunyai hak untuk memperoleh segala macam keterangan yang diperlukan yang berkaitan dengan kepentingan dan jalannya perseroan. Kewenangan tersebut merupakan kewenangan eksklusif yang tidak dapat diserahkan kepada organ lain

Sebagai suatu badan hukum, pada prinsipnya

Kekuasaan tertinggi merupakan istilah yang digunakan pada Undang-Undang No. 1 Tahun 1995 tentang Perseroan Terbatas (Lembaran Negara Republik Indonesia Tahun 1995 Nomor 13).

14 H.M.N. Purwosutjipto, 2005, Pengertian Pokok Hukum Dagang Indonesia 2: Bentuk-bentuk Perusahaan, Cet. 10, Intan Sejati Klaten, Jakarta, hlm 130 .

15 Pasal 1 angka 4 Undang-Undang Nomor 40 Tahun 2007 (Lembaran Negara Nomor 106 Tahun 2007, Tambahan Lembaran Negara Republik Indonesia Nomor 4756).

16 Tri Budiyono, 2011, Hukum Perusahaan, Telaah Yuridis terhadap UU No. 40 Tahun 2007 tentang Perseroan Terbatas, Gria Media, Salatiga, hlm. 148-149.

17 Munir Fuady, 2002, Hukum Perusahaan Dalam Paradigma Hukum Bisnis, Citra Aditya Bakti, Bandung, hlm. 43. 
perseroan terbatas dapat memiliki segala hak dan kewajiban yang dapat dimiliki oleh setiap orangperorangan, dengan pengecualian hal-hal yang bersifat pribadi, yang hanya mungkin dilaksanakan oleh orang-perorangan yang dalam hubungan tertentu dengan PT. Pemegang saham yang tergabung dalam Rapat Umum Pemegang Saham (RUPS) merupakan organ dari suatu perseroan terbatas sebagaimana tercantum dalam Pasal 1 angka 2 UU PT No. 40 Tahun 2007 bahwa organ perseroan terdiri dari Rapat Umum Pemegang Saham (RUPS), Direksi dan Dewan Komisaris. Penempatan RUPS sebagai organ perseroan yang utama tidak terlepas dari esensi pendirian suatu PT itu sendiri. Berdasarkan Pasal 1 UU PT tampak jelas bahwa PT merupakan persekutuan modal dari para pendiri PT. Sebagai pendiri PT dan sekaligus Pemegang Saham PT yang telah memberikan kontribusi modal awal (initial capital) untuk menjalankan kegiatan usaha, sudah seyogyanya setiap keputusan yang menyangkut tujuan awal (original objective) para pendiri dalam mendirikan PT berada di tangan mereka melalui lembaga RUPS. Alasan lain penempatan pemegang saham pada unsur utama adalah organ PT lainnya yaitu Direksi dan Dewan Komisaris diangkat dan diberhentikan oleh RUPS.

UU PT No. 40 tahun 2007, pada Pasal 1 ayat (4) menjelaskan mengenai gambaran kedudukan RUPS dalam sebuah perseroan terbatas sebagai berikut: "Rapat Umum Pemegang Saham selanjutnya disebut RUPS adalah organ perseroan yang mempunyai wewenang yang tidak diberikan kepada direksi atau dewan komisaris dalam batas yang ditentukan dalam undang-undang ini dan/atau anggaran dasar". Dari pengertian Pasal 1 ayat (4) ini, tampak jelas bahwa melalui RUPS tersebutlah para pemegang saham sebagai pemilik (eigenaar, owner) perseroan melakukan kontrol terhadap kepengurusan yang dilakukan Direksi maupun terhadap kekayaan serta kebijakan kepengurusan yang dijalankan manajemen perseroan. ${ }^{18}$

Secara umum, menurut Pasal 1 angka 4, RUPS sebagai organ perseroan, mempunyai ke- wenangan yang tidak diberikan kepada Direksi atau Dewan Komisaris, namun dalam batas yang ditentukan dalam Undang-Undang ini dan/atau Anggaran Dasar (AD) PT. Kemudian kewenangan RUPS tersebut, dikemukakan ulang lagi pada Pasal 75 ayat (1) yang berbunyi: RUPS mempunyai wewenang yang tidak diberikan kepada Direksi atau Dewan Komisaris dalam batas yang ditentukan dalam Undang-Undang ini dan/atau Anggaran Dasar.

RUPS sering disebut sebagai organ tertinggi dalam perseroan. Namun, pada dasarnya ketiga organ perseroan PT (RUPS, Direksi dan Dewan Komisaris) memiliki kedudukan yang sejajar dan berdampingan sesuai dengan pemisahan kewenangan (separation of power) yang diatur dalam Undang-Undang dan Anggaran Dasar. Dengan demikian, tidak dapat dikatakan RUPS lebih tinggi dari Direksi dan Dewan Komisaris. Masing-masing organ mempunyai posisi dan kewenangan sesuai dengan fungsi dan tanggung jawab yang mereka miliki. Ketentuan UU PT No. 40 Tahun 2007, berbeda dengan ketentuan UU No. 1 Tahun 1995, dimana dalam UU PT No. 1 Tahun 1995 dijelaskan RUPS adalah organ perseroan yang memegang kekuasaan tertinggi dalam perseroan yang memegang segala wewenang yang tidak diserahkan kepada direksi dan komisaris. Sedangkan dalam UU PT No. 40 Tahun 2007, ketentuan mengenai RUPS sebagai kekuasaan tertinggi dalam perseroan terbatas dihilangkan sehingga kedudukan RUPS adalah sama sebagai organ perseroan (PT) yang lain yaitu Direksi dan Dewan Komisaris.

\section{Tanggung Jawab Pemegang Saham PT menurut Hukum Positif}

Apabila status suatu PT sudah ditetapkan sebagai badan hukum oleh Menteri Hukum dan HAM, maka sejak saat itu hukum memberlakukan pemilik atau pemegang saham terpisah dari PT itu sendiri yang dikenal dengan istilah "separate legal personality" yaitu sebagai individu yang berdiri sendiri. Hal ini sebagaimana diatur dalam Pasal 9 ayat (1) UU PT No. 40 Tahun 2007, dengan demikian, pemegang saham tidak mempunyai kepentingan 
dalam kekayaan PT, sehingga pemegang saham tidak bertanggungjawab secara pribadi atas perbuatan hukum yang dilakukan atas nama PT tersebut.

Suatu perusahaan mempunyai personalitas atau kepribadian "corporate personality" berbeda dari orang yang menciptakannya, meskipun orang yang menjalankan perusahaan tersebut atau pemegang saham terus berganti, perusahaan tetap memiliki identitas sendiri terlepas dari adanya pergantian para anggota pengurus atau pemegang sahamnya. PT merupakan badan usaha dan besarnya modal perseroan tercantum dalam Anggaran Dasar (AD). Kekayaan perusahaan terpisah dari kekayaan pribadi pemilik perusahaan sehingga memiliki harta kekayaan sendiri. Setiap orang dapat memiliki lebih dari satu saham yang menjadi bukti pemilikan perusahaan. Pemilik saham mempunyai tanggung jawab yang terbatas, yaitu sebanyak saham yang dimiliki. Apabila utang perusahaan melebihi kekayaan perusahaan, maka kelebihan utang tersebut tidak menjadi tanggung jawab para pemegang saham. Apabila perusahaan mendapat keuntungan maka keuntungan tersebut dibagikan sesuai dengan ketentuan yang ditetapkan. Pemilik saham akan memperoleh bagian keuntungan yang disebut dividen yang besarnya tergantung pada besar-kecilnya keuntungan yang diperoleh perseroan terbatas.

Hukum perseroan seperti yang dirumuskan pada Pasal 3 ayat (1) UU PT No.40 Tahun 2007, secara imajiner membentangkan tembok pemisah antara perseroan dengan pemegang saham untuk melindungi pemegang saham dari segala tindakan, perbuatan dan kegiatan perseroan berupa: ${ }^{19}$

a. Tindakan, perbuatan dan kegiatan perseroan, bukan tindakan pemegang saham.

b. Kewajiban dan tanggung jawab perseroan bukan kewajiban dan tangung jawab pemegang saham. Jika demikian halnya, perseroan sebagai badan hukum, adalah makhluk hukum ( $a$ creature of the law) yang memiliki hal-hal berikut:

1) Kekuasaan (power) dan kapasitas yang dimilikinya karena di- berikan hukum kepadanya, dan berwenang berbuat dan bertindak sesuai dengan kewenangan yang diberikan, dalam Anggaran Dasar (AD).

2) Mempunyai kekuasaan diatur secara tegas (express power) seperti untuk memiliki kekayaan, menggugat, dan digugat tas nama perseroan.

3) Tetapi ada juga kekuasaan yang bersifat (implicit power) yakni berwenang melakukan apa saja, asal dilakukan secara reasonable dan penting (reasonably necessary) untuk perseroan, seperti menguasai atau mentransfer barang, meminjamkan uang, memberi sumbangan, dan sebagainya.

Tindakan yang jatuh di luar kekuasaan yang disebut dengan tegas (express power) maupun kekuasaan implisit (implicit power), dapat dikategorikan ultra virus yang berarti berada di luar kegiatan dan di luar wewenang (unauthorized activities). Menurut ketentuan hukum perusahaan terjadi pemisahan (separate) dan perbedaan (distinct) antara perseroan dengan pemilik atau pemegang saham? Pemisahan dan perbedaan terjadi, terhitung sejak perseroan mendapat keputusan pengesahan dari Menteri Hukum dan HAM yang digariskan Pasal 9 ayat (1) UU PT No. 40 Tahun 2007: (1) sejak tanggal pengesahan tersebut, perseroan terpisah (separate) dari pemegang saham, pendiri dan pengurus dan,; (2) juga sejak saat itu perseroan berbeda (distinct) dari person hukum yang lain

Sutan Remy Sjahdeni mengemukakan perseroan merupakan legal entity yang berbeda dan terpisah dari pemegang saham PT. Oleh sebab itu, perseroan dalam melakukan fungsi hukumnya bukan bertindak sebagai kuasa dari para pemegang saham tetapi bertindak untuk dan atas nama dirinya sendiri. Para pemegang saham bukan merupakan para pihak dari perjanjian yang dibuat oleh PT dengan pihak lain. Oleh karena itu, pemegang saham juga tidak berhak memaksa pihak lain untuk me-

\footnotetext{
9 Philip J. Scaletta Jr., dalam Zarman Hadi, 2011, Karakteristik Tanggung Jawab Pribadi Pemegang Saham, Komisaris dan Direksi dalam Perseroan Terbatas, UB Press, Malang, hlm. 31.
} 
laksanakan kewajibannya yang ditentukan dalam perjanjian itu. Sebagai konsekuensinya, pihak ketiga tidak dapat menagih dan menggugat PT atas kewajiban hukum dari pemegang saham perseroan itu. Sebaliknya, ia juga tidak berhak menagih pihak ketiga atas kewajiban yang harus dibayarkan kepada pemegang saham perseroan itu. Dengan demikian, maka antara pemegang saham dan PT merupakan pihak yang terpisah. Para pemegang saham tidak bisa dituntut untuk melunasi hutanghutang perseroan, walaupun dirinya adalah pemiliknya. ${ }^{20} \mathrm{Hal}$ ini disebabkan para pemegang saham sudah mengadakan perjanjian yang isinya masingmasing pihak telah memisahkan atau melepaskan sebagian harta kekayaan milik pribadinya menjadi harta kekayaan perseroan terbatas yang dipisahkan dari harta kekayaan pribadinya, sehingga tanggungjawab pemegang saham hanya terbatas pada harta kekeyaan milik pribadinya yang telah dimasukkan ada PT.

Saham yang dimiliki pemegang saham sebagai bukti kepemilikannya atas sebagian perseroan, pada umumnya hanya memberi hak kepada pemegang saham untuk mengeluarkan suara dalam RUPS, menerima deviden, menerima persentase aset perseroan secara proporsional sesuai dengan jumlah saham yang dimiliki, apabila perseroan dilikuidasi. Selanjutnya, pemegang saham sebagai pemilik, hanya mempunyai hak kontrol tidak langsung atas operasional sehari-hari perseroan dan atas segala kebijaksanaan Direksi. Akan tetapi, pemegang saham tidak memikul tanggung jawab atas pelaksanaan fungsi Direksi. Memang semakin banyak saham yang dimiliki seorang pemegang saham, semakin besar kekuasaan kontrol yang dapat dilakukannya.

Selain hal-hal yang dijelaskan di atas, salah satu keuntungan yang paling besar diperoleh dan dinikmati (enjoy) pemegang saham, adalah tanggung jawab terbatas (limited liability). Keuntungan ini, diberikan undang-undang kepadanya, sebagaimana yang ditegaskan Pasal 3 ayat (1) UU PT No. 40 Tahun 2007 yaitu: a. Pemegang saham perseroan, tidak bertanggung jawab secara pribadi (personal liability) atas perikatan yang dibuat atas nama perseroan maupun atas kerugian yang dialami perseroan;

b. Risiko yang ditanggung pemegang saham, hanya sebesar investasinya atau tidak melebihi saham yang dimilikinya pada perseroan;

c. Dengan demikian, pada prinsipnya pemegang saham tidak bertanggung jawab secara pribadi atau secara individual atas utang perseroan.

Prinsip ini dipertegas lagi dalam penjelasan Pasal 3 ayat (1) UU PT 2007, bahwa pemegang saham hanya bertanggung jawab sebesar setoran atas seluruh saham yang dimilikinya dan tidak meliputi harta kekayaan pribadinya. Prinsip separate entity dan corporate entity yang melahirkan tanggung jawab terbatas (limited liability) pemegang saham, menimbulkan beberapa konsekuensi antara lain: ${ }^{21}$

a. Peseroan sebagai bahan hukum merupakan unit hukum (legal unit) dengan kewenangan dan kapasitas yang terpisah dari pemegang saham untuk menguasai kekayaan (property), membuat kontrak, menggugat dan digugat, melanjutkan hidup dan eksistensi meskipun pemegang saham berubahan Direksi diberhentikan atau diganti.

b. Harta kekayaan, hak dan kepentingan, serta tanggung jawab perseroan terpisah dari pmegang saham.

c. Selanjutnya pemegang saham menurut hukum sesuai dengan ketentuan Pasal 3 ayat (1) UU PT 2007, mempunyai imunitas (immunity) dari kewajiban dan tanggung jawab perseroan, karena antara pemegang saham dengan perseroan terdapat perbedaan (distinction) dan pemisahan (separation) personalitas hukum (legal personality).

Selain UU PT 1995 dan UU PT 2007, dalam Kitab Undang-Undang Hukum Dagang (KUHD) juga dijelaskan mengenai tanggungjawab terbatas pemegang saham sebagaimana diatur dalam Pasal

\footnotetext{
Sutan Remy Sjahdeni, “Tanggung Jawab Pribadi Direksi dan Komisaris”, Jurnal Hukum Bisnis, Vol. 14, Juli 2001, hlm. 108.
} 
40 ayat (2) KUHD yang berbunyi: "Persero-pesero atau pemegang-pemegang saham atau sero tidak bertanggungjawab lebih pada jumlah penuh dari saham-saham itu". Pasal 40 KUHD ini menunjukkan adanya pembatasan tanggung jawab terhadap para pemegang saham. Ini berarti segala risko kerugian sepenuhnya dibebankan kepada kumpulan modal yang berasal dari pendiri dan atau orangorang pemegang saham yang dipisahkan dari harta kekayaannya dan merupakan kekayaan PT bukan kepada harta kekayaan pemegang sahamnya. Pasal 40 KUHD ini dipertgeas kembali dalam Pasal 3 UU PT No. 1 Tahun 1995 maupun UU PT No. 40 Tahun 2007. Pasal 3 UU PT Tahun 1995 berbunyi: "Pemegang saham tidak bertanggungjawab secara pribadi atas perikatan yang dibuat atas nama PT dan tidak bertanggung jawab atas kerugian PT melebihi nilai saham yang diambilnya". Sedangkan Pasal 3 ayat (1) UU PT tahun 2007 berbunyi: "Pemegang saham tidak bertanggungjawab secara pribadi atas perikatan yang dibuat atas nama perseroan dan tidak bertanggung jawab atas kerugian perseroan melebihi saham yang dimiliki".

Dari penjelasan tersebut, maka PT mempunyai harta kekayaan sendiri yang terpisah dari harta kekayaan perseronya, dan didapat dari pemasukan para pesero (pemegang saham) yang berupa modal dasar, modal yang ditempatkan dan modal yang disetor penuh. Harta kekayaan ini sengaja diadakan dan diperlukan sebagai alat untuk mengejar tujuan perseroan dalam hubungan hukumnya di masyarakat, misalnya dalam rangka membuat perjanjian-perjanjian dengan pihak ketiga. Harta kekayaan ini menjadi jaminan perikatan yang telah dibuat oleh perseroan dengan pihak ketiga. Dengan demikian, apabila dikemudian hari timbul tanggung jawab hukum yang harus dipenuhi oleh suatu PT, maka pertanggungjawabannya semata-mata dibebankan pada harta yang terkumpul dalam perseroan tersebut. Oleh karenanya, secara hukum PT mempunyai pertanggungjawaban sendiri, walapun harta kekayaan itu berasal dari para pesero atau pemegang saham, harta itu terpisah sama sekali dengan harta kekayaan masing-masing pesero atau pemegang saham.

\section{Beralihnya Tanggung Jawab Terbatas Menjadi Tanggung Jawab Tak Terbatas Pemegang Saham Perseroan Terbatas}

Pada keadaan dan peristiwa tertentu, prinsip keterpisahan (separate) perseroan dari pemegang saham, secara kasuistik perlu disingkirkan dan dihapus dengan cara menembus tembok atau tabir perseroan atas perisai tanggung jawab terbatas atau (limited liability). Konsekuensi hukum atas penyingkapan tabir atau tembok perlindungan itu, yang lazim disebut piercing the corporate veil. ${ }^{22}$ Dengan kata lain, prinsip tanggung jawab terbatas Pemegang Saham tidak berlaku secara mutlak.

Dalam hukum positif Indonesia, kemungkinan untuk mengecualikan prinsip tanggung jawab terbatas tersebut dimungkinkan dalam hal-hal sebagaimana tercantum dalam Pasal 3 ayat (2) UU PT No. 40 Tahun 2007 yaitu sebagai berikut: ${ }^{23}$

a. Persyaratan perseroan atau PT sebagai badan hukum belum atau tidak terpenuhi. Ketentuan tentang tanggung jawab perbuatan hukum atas nama perseroan yang belum memperoleh status badan hukum, merujuk pada Pasal 14 UU Nomor 40 Tahun 2007 yang dapat diklasifikasi sebagai berikut:

1) Perbuatan hukum dilakukan semua anggota Direksi bersama-sama semua pendiri dan semua anggota Dewan Komisaris. Pasal 14 ayat (1) UU PT No. 40 Tahun 2007, menjelaskan bahwa perbuatan hukum atas nama perseroan yang belum memperoleh status badan hukum, harus atas persetujuan semua pendiri, anggota Direksi dan anggota Dewan Komisaris. Akibatnya menjadi tanggung jawab secara tanggung renteng (hoofdeljk,

\footnotetext{
22 Piercing the corporate veil adalah suatu doktrin yang mengajarkan bahwa ada kemungkinan membebankan tanggung jawab atas pihak lain yang bukan perusahaan itu sendiri, sungguhpun perbuatan tersebut dilakukan secara sah oleh dan atas nama perusahaan sebagai badan hukum. Munir Fuady, Op.cit, hlm. 7.

23 M. Yahya Harahap, "Separate Entity, Limited Liability dan Piercing The Corporate Veil”, Jurnal Hukum Bisnis, Vol. 26, No. 3, 2007 , hlm. 45-47.
} 
aansprakeljk, jointly and severally liable) dari semua pendiri, anggota Direksi dan anggota Dewan Komisaris.

2) Perbuatan hukum dilakukan oleh pendiri atas nama perseroan. Apabila perbuatan hukum dilaukan pendiri atas nama perseroan yang belum memperoleh status badan hukum, maka menurut Pasal 14 ayat (2) UU PT 2007, perbuatan hukum itu menjadi tanggung jawab pribadi (persoonljke aansprakeljkheid, personal liability) pendiri yang bersangkutan, dan tidak mengikat perseroan.

Pasal 3 ayat (2) huruf a UU PT No. 40 Tahun 2007 yang menyatakan bahwa pemegang saham bertanggungjawab pribadi bila persyaratan perseroan sebagai badan hukum belum atau tidak terpenuhi sama dengan Pasal 3 ayat (2) huruf a UU PT No. 1 Tahun 1995. ketentuan UU PT Tahun 1995 dan UU PT Tahun 2007, serta sama juga dengan Pasal 39 KUHD yang menyatakan: "Selama pendaftaran dan pengumuman tersebut belum diselengarakan, sekalian pengurusnya adalah orang demi orang dan masingmasing bertanggungjawab untuk seluruhnya, atas tindakan mereka terhadap pihak ketiga".

Dalam KUHD, tidak ada ketentuan pemegang saham bertanggungjawab secara pribadi, bila ia satu-satunya pemegang saham. Akan tetapi, Mahkamah Agung Republik Indonesia pada tahun 1973 (sebelum lahirnya UU No. 1 Tahun 1995), berpendapat sama dengan Pengadilan Tinggi Jakarta, perseroan yang pemegang sahamnya 1 (satu) orang, maka harta pribadi pemegang saham tersebut dapat disita untuk pembayaran utang yang dibuat perseroan. ${ }^{24}$

b. Pemegang Saham yang bersangkutan baik langsung maupun tidak langsung dengan itikad buruk memanfaatkan perseroan sematamata untuk kepentingan pribadi. Itikad buruk atau penggunaan tidak wajar dianggap terjadi, apabila terdapat indikasi berikut, antara lain:

1) Menipu kreditor (defrauding creditor).

2) Kapital tipis (thin capatalization) yakni perseroan kekurangan modal atau berada dalam keadaan "under capitalization".

3) Perampokan (looting) yakni mentransfer aset perseroan kepada pemegang saham transfer mana tiada lain dari perjanjian transaksi yang berlawanan dengan hukum antar perseroan dengan pemegang saham, untuk menipu kreditor.

4) Mengakali peraturan perundangundangan (circumventing a statute), misalnya perseroan dilarang melakukan usaha retail disuatu tempat. Untuk mengakali larangan itu, dimana seluruh asetnya dimiliki perseroan tersebut.

5) Menghindari kewajiban yang ada (evoiding an existing obligation), misalnya untuk menghindari memenuhi tanggung jawabnya atas pejanjian yang dibuat dengan pihak ketiga (kreditor). Cara yang sering dilakukan dengan jalan mendirikan perseroan anak (subsidiary). Perseroan baru itu atau perseroan anak tadi mengklaim, bahwa dia tidak ada sangkut pautnya dengan perseroan lama. (parent company) dan tidak bertanggung jawab terhadap kontrak yang dibuat perseroan lama, meskipun dirinya melanjutkan usaha persoalan lama.

c. Pemegang Saham yang bersangkutan terlibat dalam perbuatan melawan hukum yang dilakukan oleh perseroan. Apabila pemegang saham terlibat atau bersekongkol dengan perseroan melakukan perbuatan melawan hukum, yang menimbulkan kerugian kepada pihak lain. Penerapan alasan ini tidak rumit. Hal yang perlu dibuktikan ada fakta yang menunjukkan keterlibatan pemegang saham dalam perbuatan melawan hukum yang dilakukan perseroan.

d. Pemegang Saham yang bersangkutan baik langsung maupun tidak langsung secara me-

24 Erman Rajagukguk, "Pengelolaan Perusahaan Yang Baik: Tanggung Jawab Pemegang Saham, Komisaris dan Direksi”, Jurnal Hukum Bisnis, Vol. 26, No. 3, 2007, hlm. 15-16. 
lawan hukum menggunakan kekayaan perseroan, yang mengakibatkan kekayaan perseroan menjadi tidak cukup untuk melunasi utang perseroan.

Dari keempat isi Pasal 3 UU PT tersebut, Gunawan Widjaya, mengemukakan hal yang menyebabkan terjadinya piercing the corporate veil yaitu: $:^{25}$

1) Dalam hal yang pertama, jelas pemegang saham, tidak secara serius menghendaki status pertanggungjawaban terbatas, yang hanya dapat diperoleh segera setelah perseroan terbatas didirikan tersebut memperoleh pengesahan dari Menteri Hukum dan Hak Asasi Manusia. Dengan mengabaikan proses dan formalitas yang selayaknya dan seharusnya ditempuh, pendiri perseroan terbatas daoat dikatakan tidak bermaksud untuk secara sungguh-sungguh mendirikan suatu peerseroan terbatas. Bahkan dalam ketentaun Pasal 10 ayat (9) UU PT No. 40 Tahun 2007 yang menyatakan bahwa jika dalam jangka waktu 60 (enam puluh) hari terhitung sejak tanggal akta pendirian ditandatangani permohonan untuk pengesahan dan memperoleh status badan hukum tidak dimajukan kepada Menteri Hukum dan HAM, maka pendirian menjadi batal sejak lewatnya jangka waktu tersebut dan Perseroan yang belum memperoleh status badan hukum bubar karena hukum dan pemberesannya dilakukan oleh pendiri. Tidak diperolehnya status badan hukum tersebut, bukan hanya semata-mata terjadi karena tidak diajukannya permohonan pengesahan sebagai badan hukum, melainkan dapat terjadi karena berbagai hal. Halhal tersebut dapat terjadi misalnya, karena pendiri tidak mau melakukan penyetoran modal sebagaimana telah ditentukan sebelumnya,pendiri tidak memberikan kuasa kepada pengurus perseroan untuk melakukan kegiatan yang diperlukan sedangkan pendiri itu sendiri tidak mau bertindak atas nama perseroan,dan lain sebagainya;

2) Hal kedua terkait dengan teori keagenan, di mana pemegang saham dengan itikad buruk telah memanfaatkan perseroan untuk kepentingan dirinya pribadi.Dalam konteks yang demikian, berarti perseroan semata-mata hanya melaksanakan apa yang menjadi tujuan dan objektif dari pemegang saham. Pemegang saham dalam hal ini berlindung di balik pertanggungjawaban terbatas perseroan,sedangkan perseroan sendiri dimanfaatkan untuk kepentingan pribadinya. Jadi jelaslah dalam konteks ini,pemegang saham yang tidak memiliki itikad baik dan dilindungi oleh hukum. Piercing the corporate veil belaku dalam hal ini bagi pemegang saham yang memanfaatkan perseroan untuk kepentingannya pribadi.

3) Hal ketiga ini menunjukkan pada tindakan pemegang saham yang secara bertentangan dengan hukum (fraud). Dalam hal ini perlu diperhatikan adagium bahwa siapa yang telah menerbitkan kerugian pada seseorang lain,bertanggung jawab atas kerugian yang diterbitkannya tersebut. Sebagai suatu artificial person, perseroan terbatas tidaklah memiliki kehendak. Dalam keadaan di mana kehendak perseroan adalah kehendak pemegang saham,maka jelas yang bertanggung jawab adalah pemegang saham tersebut.

4) Hal keempat terkait dengan dengan penggunaan harta kekayaan secara tidak sah yang menyebabkan harta kekayaan perseroan menjadi berkurang sehingga perseroan tidak dapat melunasi seluruh kewajibannya kepada kreditor perseroan.

Ketentuan Pasal 3 ayat (2) UU PT No. 40 Tahun 2007 tentang Perseroan Terbatas tidak ada satu ketentuanpun yang menyatakan pihak mana yang sebenarnya dilindungi dengan diberlakukannya prinsip piercing the corporate veil. Namun demikian dengan melihat pada ketentuan yang dinyatakan

25 Gunawan Widjaya, 2008, Risiko Hukum Sebagai Direksi, Komisaris dan Pemilik PT, Forum Sahabat, Jakarta, hlm. 38-40. 
dalam Pasal 3 ayat (2) UU PT No. 40 tahun 2007 dapat diketahui bahwa perlindungan diberikan kepada kreditor PT. Sebagai perbandingan dengan ketentuan UU PT di atas, yurisprudensi Common Law menyimpulkan adanya tiga doktrin umum bagi kemungkinan dapat dilanggarnya prinsip tanggung jawab terbatas atau dimungkinkannya Piercing The Corporate Veil, yakni: ${ }^{26}$

1. Doktrin "Instrumentality", yang pendekatannya mengacu pada 3 (tiga) faktor sebagai berikut:

a. Adanya kontrol/pengendalian atas PT, sehingga PT tidak mempunyai eksistensi yang mandiri.

b. Pengendalian tersebut berpengaruh atas dilakukannya tindakan melalaikan kewajiban.

c. Atas tindakan lalai tersebut menimbulkan kerugian.

2. Doktrin "Alter Ego", yang berpendapat bahwa Piercing The Corporate Veil dapat diterapkan dalam hal:

a. Kepentingan Pemilik Saham mengalahkan kepentingan PT; dan

b. Sulit untuk membedakan atau mengenali entitas pribadi Pemegang Saham dari entitas PT yang bersangkutan.

3. Doktrin "identity", yang menyerahkan permasalahan kesatuan atau pemisahan kekayaan perseroan dalam pembuktian di pengadilan secara per kasus.

Tujuan dari dimungkinkannya penghapusan tanggung jawab terbatas suatu PT sebagaimana disimpulkan dari penjelasan Pasal 3 ayat (2) adalah agar suatu PT didirikan tidak semata-mata sebagai alat yang dipergunakan untuk memenuhi tujuan pribadi Pemegang Saham, sehingga terjadi pembauran harta kekayaan pribadi Pemegang Saham dan harta kekayaan PT, atau antara harta kekayaan Pemegang Saham dan harta kekayaan PT tidak da- pat lagi dibedakan.

\section{Penutup}

Tanggung jawab pemegang saham menurut hukum positif pada prinsipnya adalah terlihat terbatas pada modal (saham) yang disetorkan atau dimiliki. Hal ini dapat diketahui dari 3 (tiga) ketentuan Undang-Undang yaitu Kitab Undang-Undang Hukum Dagang (KUHD), UU PT No. 1 Tahun 1995 dan UU PT No. 40 Tahun 2007, yang masingmasing berbunyi sebagai berikut: Pertama, Pasal 40 ayat (2) KUHD yang berbunyi "Persero-pesero atau pemegang-pemegang saham atau sero tidak bertanggungjawab lebih pada jumlah penuh dari saham-saham itu", ${ }^{27}$ Kedua, Pasal 3 UU PT No. 1 Tahun 1995 berbunyi "Pemegang saham tidak bertanggungjawab secara pribadi atas perikatan yang dibuat atas nama PT dan tidak bertanggung jawab atas kerugian PT melebihi nilai saham yang diambilnya", ${ }^{28}$ dan Ketiga, Pasal 3 UU PT No. 40 tahun 2007 berbunyi "Pemegang saham tidak bertanggungjawab secara pribadi atas perikatan yang dibuat atas nama perseroan dan tidak bertanggung jawab atas kerugian perseroan melebihi saham yang dimiliki". ${ }^{29}$

Bilamana Pemegang Saham bertanggung jawab secara pribadi terhadap kerugian suatu Perseroan Terbatas dimungkinkan dalam hal-hal sebagaimana tercantum dalam Pasal 3 ayat (2) UU PT No. 1 Tahun 1995 dan UU PT No. 40 Tahun 2007, yaitu apabila persyaratan perseroan atau PT sebagai badan hukum belum atau tidak terpenuhi; Pemegang Saham yang bersangkutan baik langsung maupun tidak langsung dengan itikad buruk memanfaatkan perseroan semata-mata untuk kepentingan pribadi; Pemegang Saham yang bersangkutan terlibat dalam perbuatan melawan hukum yang dilakukan oleh perseroan; dan Pemegang Saham yang bersangkutan baik langsung maupun tidak langsung secara melawan hukum menggunakan ke-

\footnotetext{
James D. Cox, et al., 1997, Corporations, Aspen Law \& Business, New York, hlm. 112-113.

Pasal 40 ayat (2) Kitab Undang-Undang Hukum Dagang (Staatsblad (Stb) Tahun 1938 No. 276 tanggal 17 Juli 1938).

28 Pasal 3 Undang-Undang Nomor 1 Tahun 1995 tentang Perseroan Terbatas (Lembaran Negara Republik Indonesia Nomor 13 Tahun 1995 , Tambahan Lembaran Negara Republik Indonesia Nomor 3587).

29 Pasal 3 Undang-Undang Nomor 40 Tahun 2007 tentang Perseroan Terbatas (Lembaran Negara Nomor 106 Tahun 2007 , Tambahan Lembaran Negara Republik Indonesia Nomor 4756).
} 
kayaan perseroan, yang mengakibatkan kekayaan perseroan menjadi tidak cukup untuk melunasi utang perseroan. Selain ketentuan Pasal 3 ayat (2) huruf a UU PT No. 1 Tahun 1995 dan UU PT No. 40 Tahun 2007, juga diatur dalam Pasal 39 KUHD yang menyatakan: "Selama pendaftaran dan pengumuman tersebut belum diselengarakan, sekalian pengurusnya adalah orang demi orang dan masingmasing bertanggungjawab untuk seluruhnya, atas tindakan mereka terhadap pihak ketiga". ${ }^{30}$

\section{DAFTAR PUSTAKA}

\section{A. Buku}

Budiyono, Tri, 2007, Hukum Perusahaan, Telaah Yuridis terhadap UU No. 40 Tahun 2007 tentang Perseroan Terbatas, Gria Media, Salatiga.

Daniel V. Davidson, et al., 1987, Comprehensive Business Law, Principle and Cases, Kent Publishing Company, Boston Massachusetts, Second Edition.

Fuady, Munir, 2002, Doktrin-doktrin Modern dalam Corporate law, Citra Aditya bakti, Bandung. 2003, Hukum Perusahaan Dalam Paradigma Hukum Bisnis, Citra Aditya Bakti, Bandung.

Hadi, Zarman, 2011, Karakteristik Tanggung Jawab Pribadi Pemegang Saham, Komisaris dan Direksi dalam Perseroan Terbatas, UB Press, Malang

Harahap, M. Yahya, 2009, Hukum Perseroan Terbatas, Sinar Grafika, Jakarta.

Hartono, Sri Redjeki, 1985, Bentuk Bentuk Kerjasama Dalam Dunia Niaga, Semarang. 2000, Kapita Selekta Hukum Perusahaan, CV. Mandar Maju, Bandung.

James, D Cox, et al., 1997, Corporations, Aspen Law \& Business, New York.

Purwosutjipto, H.M.N., 1995, Pengertian Pokok Hukum Dagang Indonesia 1: Pengetahuan Dasar Hukum Dagang, Djambatan, Jakarta. 2005, Pengertian Pokok Hukum Dagang Indonesia 2: Bentuk-bentuk Perusahaan, Cet. 10, Percetakan Intan Sejati Klaten, Jakarta.

Saliman, Abdul R, et al., 2004, Esensi Hukum Bisnis Indonesia, Kencana, Jakarta.

Simanjuntak, Cornelius, 2009, Organ Perseroan
Terbatas, Sinar Grafika, Jakarta.

Suryatin, R., 1982, Hukum Dagang, Penerbit Pradnya Paramita, Jakarta.

Widiyono, Try, 2008, Direksi Perseroan Terbatas, Keberdaan, Tugas, Wewenang dan Tanggung Jawab, Edis Kedua, Ghalia Indonesia, Bogor.

Widjaya, I.G. Rai, 2003, Hukum Perusahaan, MegaPoin, Blanc, Jakarta.

Wijaya, Gunawan, 2009, Risiko Hukum Sebagai Direksi, Komisaris \& Pemegang Saham, Penerbit Forum Sahabat, Jakarta.

Yani, Ahmad et al., 1999, Seri Hukum Bisnis Perseroan Terbatas, Raja Grafindo, Jakarta.

\section{B. Artikel dalam Antologi}

Henry Hansmann, et al., "What is: Corporate Law?", dalam Reiner Kraakman, et al., 2004, The Anatomy of Corporate Law A Comparative and Functional Approach, Oxford University Press, New York.

\section{Artikel Jurnal}

Harahap, M. Yahya, "Separate Entity, Limited Liability, dan Piercing The Corporate Veil", Jurnal Hukum Bisnis, Vol. 26, No. 3, 2007.

Khairandy, Ridwan, "Perseroan Terbatas Sebagai Badan Hukum", Jurnal Hukum Bisnis, Vol. 26, No. 3, 2007.

Rajagukguk, Erman, "Pengelolaan Perusahaan Yang Baik: TanggungJawab Pemegang Saham, Komisaris dan Direksi", Jurnal Hukum Bisnis, Vol. 26, No. 3, 2007.

Sjahdeni, Sutan Remy, "Tanggung Jawab Pribadi Direksi dan Komisaris", Jurnal Hukum Bisnis, Vol. 14, Juli 2001. 
D. Peraturan Perundang-undangan

Kitab Undang-Undang Hukum Dagang (KUHD) (Staatsblad Tahun 1938 No. 276 tanggal 17 Juli 1938).

Undang-Undang Nomor 1 Tahun 1995 tentang Perseroan Terbatas (Lembaran Negera Republik Indonesia Nomor 13 Tahun 1995,
Tambahan Lembaran Negara Republik Indonesia Nomor 3587).

Undang-Undang Nomor 40 Tahun 2007 tentang Perseroan Terbatas (Lembaran Negera Republik Indonesia Nomor 106 Tahun 2007, Tambahan lembaran Negara Republik Indonesia Nomor 4756). 